\title{
Micro-EDXRF, SEM-EDS and OM characterisation of tin soldering found in handle attachments of Roman situlae from Conimbriga (Portugal)
}

\author{
Lopes F. ${ }^{\text {a,b,c }}$, Silva R.J.C. ${ }^{\text {b,* }}$, Araújo M.F. ${ }^{a}$, Correia, V.H. ${ }^{\text {d, }}$ Dias, L. ${ }^{\text {e }}$, Mirão, J. ${ }^{\text {e }}$

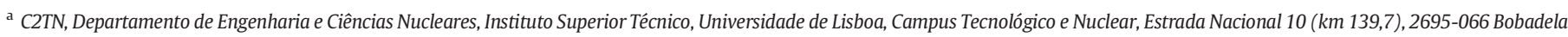 \\ LRS, Portugal \\ b i3N/CENIMAT, Departamento de Ciências dos Materiais, Faculdade de Ciências e Tecnologia, Universidade NOVA de Lisboa, Campus de Caparica, 2829-516 Caparica, Portugal \\ c Departamento de Conservação e Restauro, Faculdade de Ciências e Tecnologia, Universidade NOVA de Lisboa, Campus de Caparica, 2829-516 Caparica, Portugal \\ d Museu Monográfico e Ruínas de Conimbriga, Condeixa-a-Velha, 3150-220 Condeixa, Portugal \\ e HERCULES, Universidade de Évora, Palácio do Vimioso, Largo Marquês de Marialva, 8, 7000-809 Évora, Portugal
}

\section{A R T I C L E I N F O}

\section{Article history:}

Received 30 August 2017

Received in revised form 17 January 2018

Accepted 20 January 2018

Available online 2 February 2018

\section{Keywords:}

Soldering

Tin

Copper alloys

Microstructure

Roman

Western Iberia

\begin{abstract}
A B S T R A C T
Tin (Sn) or a Sn-rich solder applied to copper-based artefacts has been frequently used at least, since the Ancient Greece, although scarce studies have been published concerning the technology of this metallurgical joining technique.

Several filler remnants were reported to be found in a Roman collection of handle attachments of situlae or cauldrons (2nd century BCE-5th century CE) from the archaeological site of Conimbriga, a Roman city from the Lusitania Province (Portugal). All these artefacts were cast in high leaded coppers and bronzes.

The present study aims to contribute to the knowledge of Sn-rich soldering, an ancient metallurgical joining technique, by the characterisation of the fusible metallic alloy present in 10 Roman artefacts by means of micro-energy dispersive X-ray fluorescence spectrometry (micro-EDXRF), scanning electron microscopy with energy dispersive X-ray (SEM-EDS) microanalysis and optical microscope (OM) observations.

Results of studied solders show the presence of Cu-Sn alloys, with Sn contents ranging from $\delta$ to $\eta$ phase composition (30-60 wt\% Sn). As the attachments were made in leaded copper alloys, it was also observed, in some cases, the melting of the interdendritic $\mathrm{Pb}$-rich chains with long-range diffusion of the solder alloy into the substrate. The fillers compositions suggest that the handle attachments have been joined to a situla body by the soldering metallurgical process with Sn or a Sn-rich alloy. The studied leaded Cu-Sn attachments, probably formulated by local craftsman, were joined into the body of a situla or cauldron with a soft solder (soldering), a common metallurgical joint from Antiquity, although no relation was found between composition or typology and the Sn or Sn-rich solder.
\end{abstract}

@ 2018 Elsevier B.V. All rights reserved.

\section{Introduction}

Soldering is a metallurgical joining technique reported to be widely used by Sumerians, Egyptians, Greeks, Etruscans and Romans [1-4]. Soldering involves the heating and fusing of a filler (metal or an alloy) with a lower melting point than the metals or alloys to be joined. In modern practice, the term soldering (soft-soldering) is applied to low-meltingpoint solder and brazing (hard-soldering) to high-melting-point solder $[5,6]$. The temperature is the main distinction between soldering and brazing. Soldering has the ability to join metals with different compositions, it is operated at low temperatures without melting the substrate (s) and it is characterised by the heating of the filler material above its

\footnotetext{
* Corresponding author.

E-mail address: rjcs@fct.unl.pt (R.J.C. Silva).
}

liquidus temperature but under $450^{\circ} \mathrm{C}$. Brazing is characterised to use higher temperatures $\left(T>450{ }^{\circ} \mathrm{C}\right)$ [7]. These ancient joining techniques also comprise a previous aid of a flux (beeswax, borax or resin) to dissolve or disperse the oxide film of the substrate, turning on a more effective and stronger bond, after the mechanical cleaning of corrosion products from the metallic surfaces to be joined together [1,5,7-9].

Gold, silver, lead and copper-based alloys are the Ancient metals that were reported to be soldered or brazed by proper filler compositions in the Naturalis Historia by Pliny the Elder [4]. Gold joins were greatly examined from ancient jewelry, comprising several joining techniques and it was found that copper or a mixture of silver and copper was alloyed with gold and used for brazing [e.g. 3,8,10,11]. Lang and Hughes $[5,6]$ analysed 19 Roman silver objects and found the presence of $\mathrm{Cu}-\mathrm{Sn}$ brazing and $\mathrm{Sn}-\mathrm{Pb}$ soldering, concluding that $\mathrm{Sn}-\mathrm{Pb}$ soldering was mainly used to attach handles and for repairs. They also discussed the Leyden papyrus reference about the way in which the solder should 
be used, particularly the usage of tin as sticks, buttons or grains. Published analysis of lead artefacts are mainly focused on pipes for Roman hydraulic system and show the use of welding with $\mathrm{Pb}$ or soldering with $\mathrm{Pb}-\mathrm{Sn}$ alloy [12-14]. Regarding the joining of Cu-based alloys, large bronze statues were predominantly studied for the characterisation of the ancient welding techniques [e.g. 2,15,16] and composition of the joining repairs [17]. Classical bronze statuettes from the British Museum were also examined and it was found that the soldering was made with Pb-Sn alloys [18].

Few studies have been focused so far on soldering pre-Roman copper-based objects. These include a Sn-rich corroded filler that was reported by Craddock [19] to be used to solder silver handles onto a copper bowl from Sumer; a semi-quantitative analysis performed on an early 5th century BCE Etruscan bronze plaque from the British Museum showed a solder with $90 \mathrm{wt} \%$ Sn, $10 \mathrm{wt} \% \mathrm{~Pb}$ [6]; more recently, Asderaki-Tzoumerkioti [1] presented a semi-quantitative analysis of the joining on a bronze Hellenistic urn evidencing the use of a Pb-Sn alloy for soldering the handle.

Also, in what concerns Sn or a Sn-rich solder applied during Roman times to Cu-based artefacts scarce studies have been performed. In these studies, the full characterisation of the solder alloy is absent and is being generally stated that a "soft-solder" implies the use of a $\mathrm{Sn}-\mathrm{Pb}$ $[2,3]$ or Pb-Sn alloy [20] or even indicates the use of different $\mathrm{Sn} / \mathrm{Pb}$ ratios [18]. Historical sources were deeply explored by Lang and Hughes $[5,6]$ but the interpretation of Pliny recipes assuming the word stagnum as tin is uncertain due to other possible interpretations of stagnum when it is used in soldering contexts. If stagnum is to be interpreted as "tin" it is confusing that in addition to stagnum Pliny mention tin (plumbum album - book XXXIII, chapter XXX [4]; [21]), "besides copper and lead, as metals that can be used for soldering" as stated by Lang and Hughes [5].
One of the reasons for the shortage of solder analysis from Cu-based alloys tableware might be the lack of filler remains in good state of conservation. Another reason might be due to geometry limitations for the analysis of the filler from intact and complete artefacts [6].

This study aims to provide an in-depth understanding of the Roman soldering practices with the characterisation of Sn-rich alloys used for soldering copper-based artefacts. To this end, a group of 10 handle attachments of situlae with soldering remains from the Roman archaeological site of Conimbriga (Portugal) was selected for elemental and microstructural study. These artefacts, originally soldered to the rim of the situla, were known to be used with decorative and functional purposes to hold the swinging handle of the situla.

Additionally, the elemental composition of one cauldron/situla body will be determined. The analysis of different components of the situla aims to evaluate probable interaction phenomena between the molten filler of the solder and the substrates (anthropomorphic attachments plus situla body).

The elemental characterisation of the solder alloy present in the selected artefacts was performed by means of micro-energy dispersive Xray fluorescence spectrometry (micro-EDXRF), scanning electron microscopy with energy dispersive X-ray (SEM-EDS) microanalysis and metallographic optical microscope (OM) observations. The elemental composition of the attachments and the situla was performed by micro-EDXRF. Results on the composition of some of these handle attachments, cast in high leaded coppers and bronzes, have been reported in a previous work [22].

The present study also focuses on the differences and complementarity of the surface analysis techniques used and how together they can give significant contributions to the understanding of the Roman metallurgy in general and soldering practices in particular.
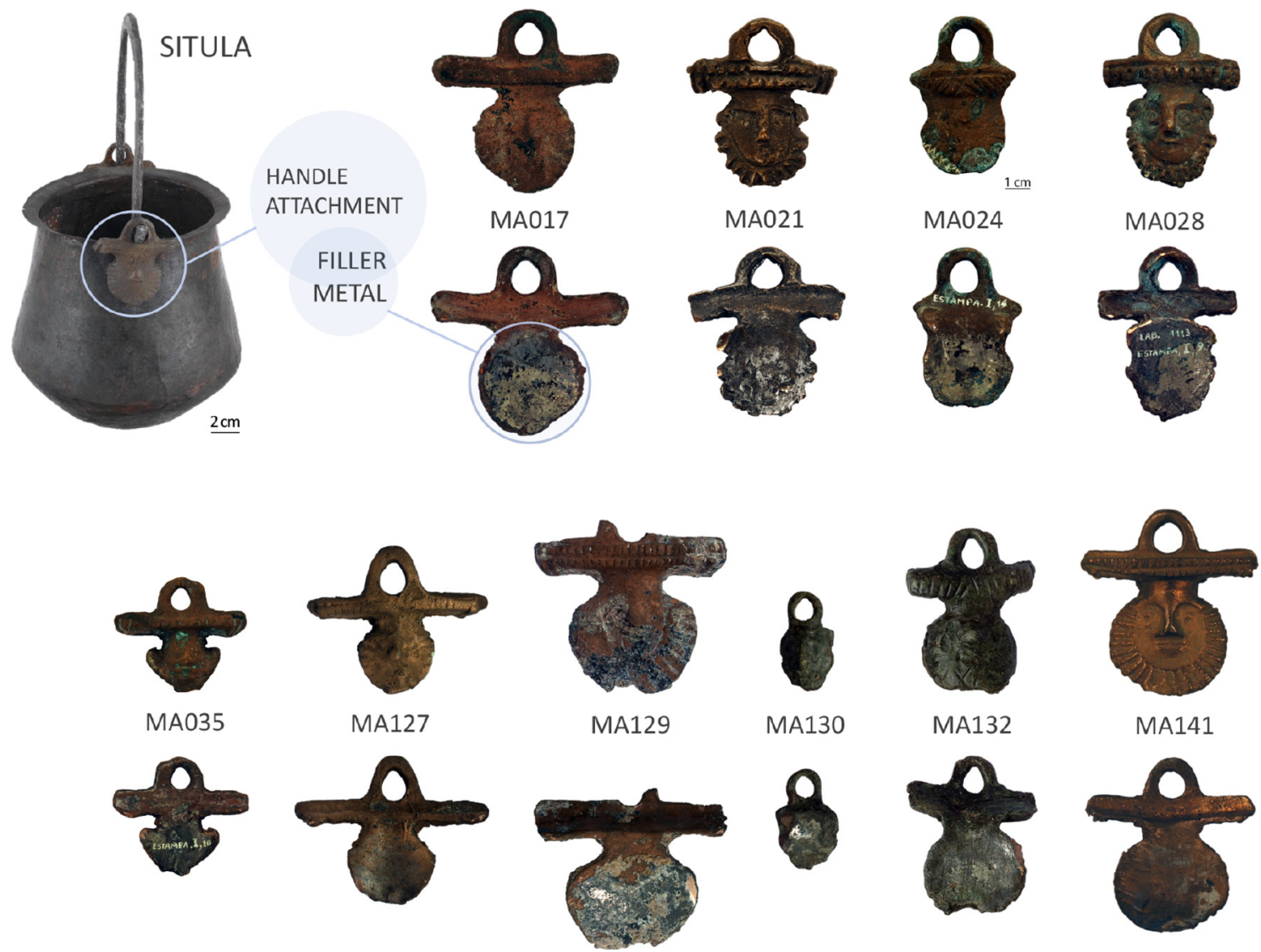

MA130
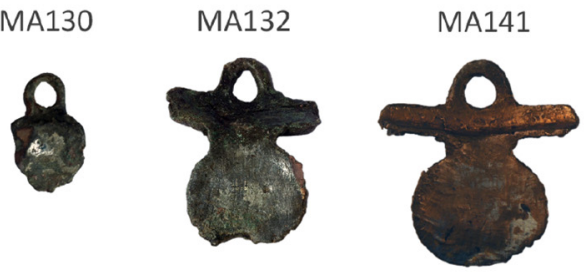

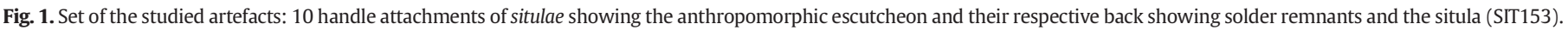


Table 1

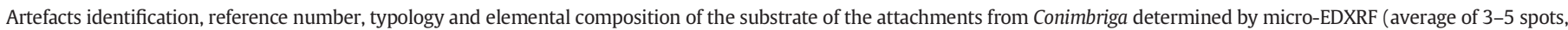
\pm (standard deviation); wt\% normalised; n.d.: not detected). The last row shows the composition of the situla (SIT153) also from the archaeological collection of Conimbriga.

\begin{tabular}{|c|c|c|c|c|c|c|c|c|c|}
\hline Artefact & Reference & Typology & $\mathrm{Cu}$ & Sn & $\mathrm{Pb}$ & $\mathrm{Zn}$ & $\mathrm{Fe}$ & $\mathrm{Ni}$ & As \\
\hline Attachment & MA017 & XIII & $\begin{array}{l}82.9 \\
(4.3)\end{array}$ & $\begin{array}{l}3.30 \\
(0.72)\end{array}$ & $\begin{array}{l}14.0 \\
(5.1)\end{array}$ & n.d. & n.d. & n.d. & n.d. \\
\hline Attachment & MA021 & $\mathrm{X}$ & $\begin{array}{l}87.0 \\
(5.9)\end{array}$ & $\begin{array}{l}3.56 \\
(0.5)\end{array}$ & $\begin{array}{l}9.66 \\
(6.04)\end{array}$ & n.d. & n.d. & n.d. & n.d. \\
\hline Attachment & MA024 & II & $\begin{array}{l}76.8 \\
(2.8)\end{array}$ & $\begin{array}{l}5.44 \\
(0.27)\end{array}$ & $\begin{array}{l}17.8 \\
(2.9)\end{array}$ & n.d. & 0.01 & n.d. & n.d. \\
\hline Attachment & MA028 & $\mathrm{X}$ & $\begin{array}{l}82.2 \\
(2.9)\end{array}$ & $\begin{array}{l}5.34 \\
(0.43)\end{array}$ & $\begin{array}{l}12.3 \\
(3.0)\end{array}$ & n.d. & $\begin{array}{l}0.08 \\
(0.07)\end{array}$ & n.d. & n.d. \\
\hline Attachment & MA035 & XI & $\begin{array}{l}94.3 \\
(1.9)\end{array}$ & $\begin{array}{l}3.85 \\
(1.57)\end{array}$ & $\begin{array}{l}1.82 \\
(0.69)\end{array}$ & n.d. & 0.02 & n.d. & $\begin{array}{l}0.21 \\
(0.06)\end{array}$ \\
\hline Attachment & MA127 & XIII & $\begin{array}{l}70.5 \\
(4.8)\end{array}$ & $\begin{array}{l}6.02 \\
(1.43)\end{array}$ & $\begin{array}{l}23.2 \\
(5.2)\end{array}$ & $<0.20$ & $\begin{array}{l}0.13 \\
(0.01)\end{array}$ & $\begin{array}{l}0.08 \\
(0.01)\end{array}$ & n.d. \\
\hline Attachment & MA129 & XIII & $\begin{array}{l}82.4 \\
(2.0)\end{array}$ & $\begin{array}{l}5.34 \\
(1.74)\end{array}$ & $\begin{array}{l}11.3 \\
(1.3)\end{array}$ & $\begin{array}{l}0.51 \\
(0.03)\end{array}$ & $\begin{array}{l}0.18 \\
(0.04)\end{array}$ & $\begin{array}{l}0.14 \\
(0.01)\end{array}$ & n.d. \\
\hline Attachment & MA130 & II & $\begin{array}{l}70.1 \\
(9.0)\end{array}$ & $\begin{array}{l}4.42 \\
(0.22)\end{array}$ & $\begin{array}{l}25.0 \\
(9.3)\end{array}$ & $<0.20$ & $\begin{array}{l}0.06 \\
(0.01)\end{array}$ & $\begin{array}{l}0.09 \\
(0.02)\end{array}$ & n.d. \\
\hline Attachment & MA132 & XIII & $\begin{array}{l}81.5 \\
(2.2)\end{array}$ & $\begin{array}{l}2.88 \\
(1.57)\end{array}$ & $\begin{array}{l}15.2 \\
(3.2)\end{array}$ & $<0.20$ & n.d. & $\begin{array}{l}0.10 \\
(0.01)\end{array}$ & n.d. \\
\hline Attachment & MA141 & XIII & $\begin{array}{l}90.1 \\
(1.8)\end{array}$ & $\begin{array}{l}1.14 \\
(0.1)\end{array}$ & $\begin{array}{l}4.40 \\
(2.05)\end{array}$ & $\begin{array}{l}3.25 \\
(0.11)\end{array}$ & $\begin{array}{l}0.34 \\
(0.04)\end{array}$ & $\begin{array}{l}0.10 \\
(0.01)\end{array}$ & $\begin{array}{l}0.71 \\
(0.38)\end{array}$ \\
\hline Situla & SIT153 & & $\begin{array}{l}94.8 \\
(0.4)\end{array}$ & $\begin{array}{l}3.91 \\
(0.43)\end{array}$ & $\begin{array}{l}0.98 \\
(0.23)\end{array}$ & n.d. & $\begin{array}{l}0.31 \\
(0.02)\end{array}$ & $\begin{array}{l}0.11 \\
(0.01)\end{array}$ & n.d. \\
\hline
\end{tabular}

\section{Materials and methods}

\subsection{Artefact description}

The Roman city of Conimbriga (2nd century BCE to 5th century CE) is an emblematic archaeological site in the province of Lusitania. Here large collections of artefacts were recovered during several archaeological excavations, since 1899. Among the metallic artefacts, there is a large collection of 50 anthropomorphic handle attachments of situlae or cauldrons with some particular features that make it unique: the diversity of typologies, some without parallel outside the Iberian Peninsula, but with clear evidence of local production [22].

In the present work 10 anthropomorphic attachments and 1 situla were analysed (Fig. 1). The anthropomorphic attachments from Conimbriga were found in various places at the archaeological site without any association with situlae or buckets. The majority of the artefacts were found during old excavations without stratigraphic registration so

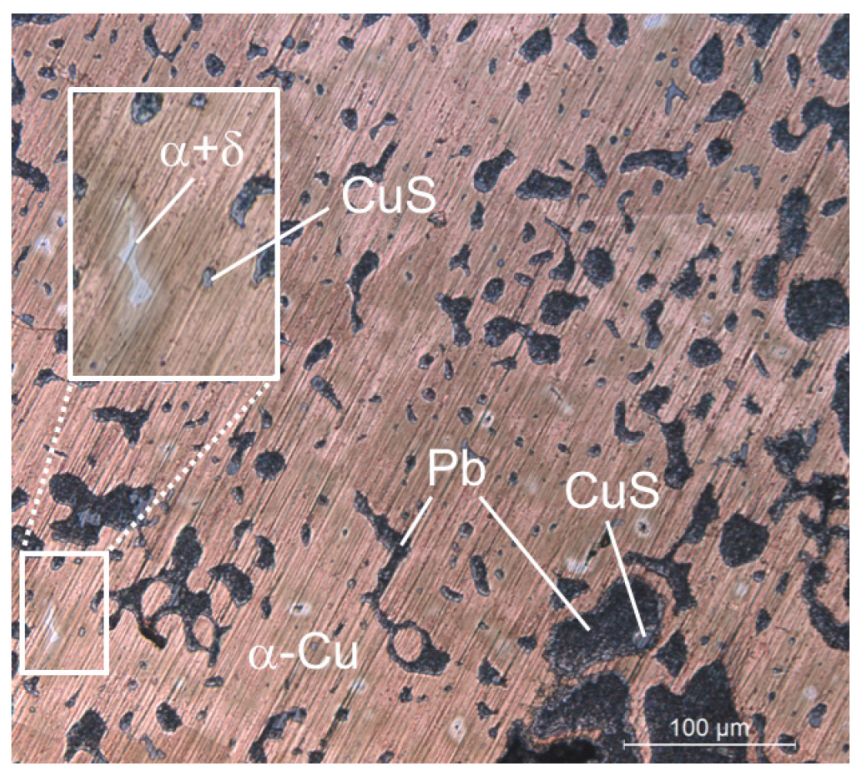

Fig. 2. As-cast structure of the artefact MA127 by OM (BF; etching 1 ). a chronological framework could not be established. The exceptions are three artefacts (MA017, MA127, MA130) found in the south baths, around 4 th or 5th century.

The anthropomorphic attachments were selected according to the presence and good conservation condition of the solder remnants present at their back (Fig. 1) from a total of 50 anthropomorphic attachments found in Conimbriga. In spite of the presence of superficial corrosion layers, in most artefacts it is possible to distinguish the presence of a solder in the back due to a distinctive grey corrosion colour.

The typologies of selected artefacts were established according to the [23] classification and include the types II, X, XI and XIII, as shown in Table 1. All are human faces that differentiated by shape, some ornaments and beard style. Type XIII is the most representative of the Conimbriga collection and is characterised by their long cross-bar above the escutcheon or face to fit into the rim of the cauldron, sometimes associated with attachments of bigger dimensions and probably belonged to larger situlae [22].

The only situla from Conimbriga findings was found in a specific stratum of the south baths (2nd-4th century) [24] (Fig. 1).

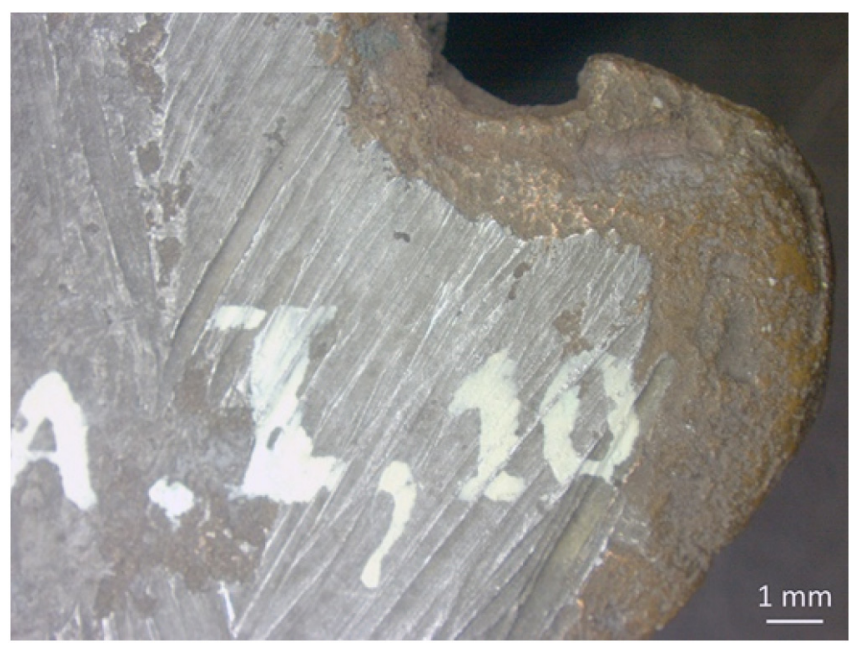

Fig. 3. SM image showing grooves and parallel scratches applied on the metallic surface under the solder at the back of the artefact MA035. 
Table 2

Micro-EDXRF results of cleaned areas of the solders from Conimbriga attachments [average of 3-5 spots, \pm (standard deviation); wt\% normalised; n.d.: not detected]; the uncleaned areas of the solders are presented in italic (1 spot of analysis).

\begin{tabular}{|c|c|c|c|c|c|c|c|}
\hline Reference & Surface & $\mathrm{Cu}$ & Sn & $\mathrm{Pb}$ & $\mathrm{Zn}$ & $\mathrm{Fe}$ & $\mathrm{Ni}$ \\
\hline \multirow[t]{2}{*}{ MA017 } & $\begin{array}{l}\text { cleaned } \\
\text { (std) }\end{array}$ & $\begin{array}{l}57.8 \\
(1.3)\end{array}$ & $\begin{array}{l}40.4 \\
(1.2)\end{array}$ & $\begin{array}{l}1.80 \\
(0.1)\end{array}$ & n.d. & n.d. & n.d. \\
\hline & uncleaned & 57.6 & 40.5 & 1.80 & n.d. & n.d. & n.d. \\
\hline \multirow[t]{2}{*}{ MA021 } & $\begin{array}{l}\text { cleaned } \\
\text { (std) }\end{array}$ & $\begin{array}{l}70.1 \\
(4.5)\end{array}$ & $\begin{array}{l}27.9 \\
(4.8)\end{array}$ & $\begin{array}{l}1.90 \\
(0.4)\end{array}$ & n.d. & $\begin{array}{l}0.16 \\
(0.03)\end{array}$ & n.d. \\
\hline & uncleaned & 77.2 & 18.3 & 4.23 & n.d. & 0.30 & n.d. \\
\hline \multirow[t]{2}{*}{ MA024 } & $\begin{array}{l}\text { cleaned } \\
\text { (std) }\end{array}$ & $\begin{array}{l}66.7 \\
(11.0)\end{array}$ & $\begin{array}{l}28.9 \\
(11.1)\end{array}$ & $\begin{array}{l}4.33 \\
(0.9)\end{array}$ & n.d. & n.d. & n.d. \\
\hline & uncleaned & 56.8 & 33.7 & 9.50 & n.d. & n.d. & n.d. \\
\hline \multirow[t]{2}{*}{ MA028 } & $\begin{array}{l}\text { cleaned } \\
\text { (std) }\end{array}$ & $\begin{array}{l}59.4 \\
(2.1)\end{array}$ & $\begin{array}{l}38.7 \\
(2.2)\end{array}$ & $\begin{array}{l}1.90 \\
(0.1)\end{array}$ & n.d. & n.d. & n.d. \\
\hline & uncleaned & 59.4 & 34.6 & 5.87 & n.d. & n.d. & n.d. \\
\hline \multirow[t]{2}{*}{ MA035 } & $\begin{array}{l}\text { cleaned } \\
\text { (std) }\end{array}$ & $\begin{array}{l}62.5 \\
(1.9)\end{array}$ & $\begin{array}{l}26.5 \\
(3.2)\end{array}$ & $\begin{array}{l}10.9 \\
(4.0)\end{array}$ & n.d. & $\begin{array}{l}0.11 \\
(0.03)\end{array}$ & n.d. \\
\hline & uncleaned & 63.2 & 28.1 & 8.57 & n.d. & n.d. & n.d. \\
\hline \multirow[t]{2}{*}{ MA127 } & $\begin{array}{l}\text { cleaned } \\
\text { (std) }\end{array}$ & $\begin{array}{l}67.6 \\
(3.2)\end{array}$ & $\begin{array}{l}27.2 \\
(3.6)\end{array}$ & $\begin{array}{l}4.57 \\
(0.7)\end{array}$ & $\begin{array}{l}0.22 \\
(0.02)\end{array}$ & $\begin{array}{l}0.22 \\
(0.08)\end{array}$ & $\begin{array}{l}0.10 \\
(0.01)\end{array}$ \\
\hline & uncleaned & 68.4 & 25.8 & 5.23 & n.d. & 0.40 & n.d. \\
\hline \multirow[t]{2}{*}{ MA129 } & $\begin{array}{l}\text { cleaned } \\
\text { (std) }\end{array}$ & $\begin{array}{l}58.4 \\
(5.1)\end{array}$ & $\begin{array}{l}32.1 \\
(3.8)\end{array}$ & $\begin{array}{l}8.6 \\
(1.4)\end{array}$ & $\begin{array}{l}0.56 \\
(0.12)\end{array}$ & $\begin{array}{l}0.17 \\
(0.05)\end{array}$ & $\begin{array}{l}0.19 \\
(0.01)\end{array}$ \\
\hline & uncleaned & 21.2 & 60.6 & 17.0 & 0.48 & 0.46 & 0.17 \\
\hline \multirow[t]{2}{*}{ MA130 } & $\begin{array}{l}\text { cleaned } \\
\text { (std) }\end{array}$ & $\begin{array}{l}41.7 \\
(0.7)\end{array}$ & $\begin{array}{l}56.7 \\
(0.6)\end{array}$ & $\begin{array}{l}1.23 \\
(0.2)\end{array}$ & $\begin{array}{l}0.12 \\
(0.01)\end{array}$ & $\begin{array}{l}0.38 \\
(0.03)\end{array}$ & n.d. \\
\hline & uncleaned & 40.4 & 49.5 & 9.20 & n.d. & 0.91 & n.d. \\
\hline \multirow[t]{2}{*}{ MA132 } & $\begin{array}{l}\text { cleaned } \\
\text { (std) }\end{array}$ & $\begin{array}{l}57.1 \\
(8.1)\end{array}$ & $\begin{array}{l}32.1 \\
(8.3)\end{array}$ & $\begin{array}{l}10.4 \\
(3.1)\end{array}$ & $\begin{array}{l}0.14 \\
(0.02)\end{array}$ & $\begin{array}{l}0.18 \\
(0.11)\end{array}$ & n.d. \\
\hline & uncleaned & 42.9 & 40.1 & 16.3 & n.d. & 0.57 & n.d. \\
\hline \multirow[t]{3}{*}{ MA141 } & cleaned & 80.9 & 12.9 & 2.80 & 2.85 & 0.34 & 0.10 \\
\hline & (std) & (3.9) & $(5.1)$ & $(1.4)$ & $(0.28)$ & $(0.02)$ & $(0.01)$ \\
\hline & uncleaned & 62.2 & 33.9 & 1.02 & 2.07 & 0.59 & n.d. \\
\hline
\end{tabular}

Table 3

Effective penetration depth ( $\mu \mathrm{m}$ ) of characteristic X-rays from hypothetic Cu-Sn solder alloys (the mass absorption coefficients were calculated using the published values in [33]).

\begin{tabular}{lll}
\hline Alloy composition & Sn-L $\alpha$ & CuK $\alpha$ \\
\hline Sn 60 wt\%/Cu 40 wt\% & 5.0 & 21.6 \\
Sn 50 wt\%/Cu 50 wt\% & 6.0 & 25.9 \\
Sn 40 wt\%/Cu 60 wt\% & 7.5 & 32.4 \\
\hline
\end{tabular}

\subsection{Methodology}

The artefacts were first examined under a Zeiss Discovery V20 Stereo Microscope (SM) at up to $150 \times$ magnification in order to observe the macroscopic features (e.g.: solder and wear marks).
Elemental and microstructural characterisation by micro-EDXRF, SEM-EDS and OM of the anthropomorphic attachments and solders was performed on a small area (diameter 2-4 $\mathrm{mm}$ ) at the back of each escutcheon, after removal of corrosion products. The cleaning procedure involved soft polishing with $1 \mu \mathrm{m}$ diamond paste in a cotton swab put in a rotary Dremel tool producing a smooth cleaned surface. Previously to the cleaning, micro-EDXRF analyses were also performed on the top surfaces of the solders.

For the OM observations and SEM-EDS microanalysis of the solder metal, different views were obtained according to the location of the solder and morphology of the substrate: plane and transverse regions exposing the interface substrate/solder. Nevertheless, all the areas analysed were affected by the generally rough surface of the substrate due to the presence of scratch lines (Fig. 3).

The elemental composition of the situla (SIT153) was also determined by micro-EDXRF in a small cleaned area at the bottom with the same cleaning procedure used in the attachments. Analysis of different components aims to evaluate probable interaction phenomena between the molten filler and the substrates; although this situla was incomplete, the missing parts were reconstructed (including handle and attachments) and no solder remnants were found.

\subsection{Micro-EDXRF}

The elemental composition was determined by micro-EDXRF spectrometer Bruker ArtTAX Pro equipped with a low-power Mo X-ray tube $(30 \mathrm{~W})$ and an electro-thermally cooled silicon drift detector with a resolution of $160 \mathrm{eV}$ at $5.9 \mathrm{keV}(\mathrm{Mn}-\mathrm{K} \alpha)$. The set of polycapillary lens and the accurate positioning system generate a microspot of primary radiation with $\sim 70 \mu \mathrm{m}$ in diameter [25]. Analytical conditions were $40 \mathrm{kV}$ of tube voltage, $0.5 \mathrm{~mA}$ of current intensity and $100 \mathrm{~s}$ of live time. Artefacts and solders were analysed in 3-5 different spots to account for possible heterogeneities, being considered the average values. Quantitative analysis was made with the WinAxil software (Canberra) using the fundamental parameter method and experimental calibration factors calculated with certified reference materials: Phosphor Bronze 551 from British Chemical Standards (BCS) and Leaded Bronze C50.01 from the British Non-Ferrous Metals Technology Centre (BNF). Results showed that experimental errors are better than $5 \%$ for major elements, except for $\mathrm{Pb}$ that reaches $8 \%$, while for minor elements can be higher. Some larger errors are mostly related to some strong matrix effects and peak overlapping (particularly $\mathrm{Cu}$ and $\mathrm{Zn} \mathrm{K}$-lines and As$\mathrm{K} \alpha$ and $\mathrm{Pb}-\mathrm{L} \alpha$ ). The quantification limits calculated are: $0.5 \%$ for $\mathrm{Sn}$; $0.2 \%$ for $\mathrm{Zn} ; 0.1 \%$ for $\mathrm{Pb}$ and $\mathrm{As} ; 0.07 \%$ for $\mathrm{Ni}$ and $0.05 \%$ for Fe. Additional experimental details were previously published elsewhere [26].
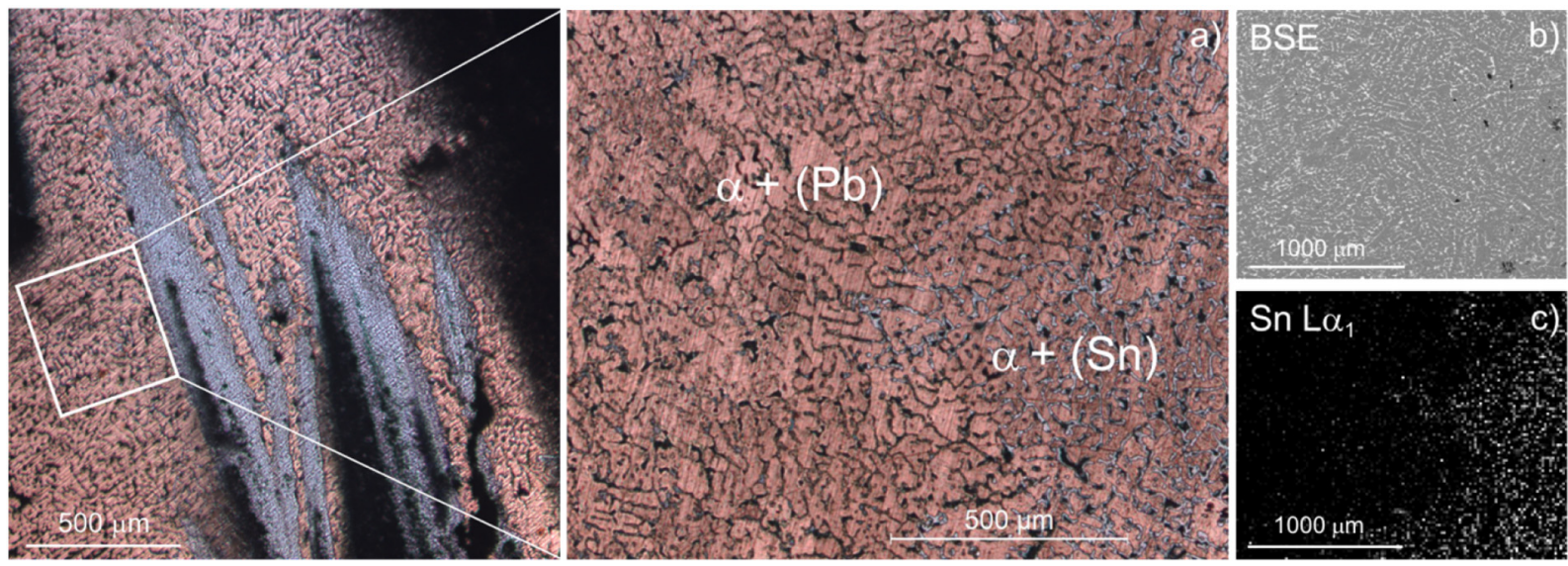

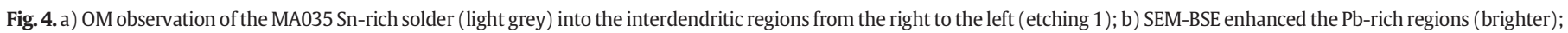
c) SEM-EDS X-ray mapping for Sn-L $\alpha$ characteristic emission shows a long-range penetration of $\mathrm{Sn}$ in the substrate resulting from the melting of Pb-rich phase. 


\section{4. $O M$}

The reflected light OM observations were carried out in a motorised Leica DMI5000 M OM coupled to a computer with the LAS V2.6 (Leica M.) and multifocus module software [27], at different magnifications under bright field (BF) illumination. BF observations in some cases were performed on etched surfaces with a solution of $10 \%$ ferric chloride (etching 1) to reveal microstructural features of the $\alpha$ copper matrix (attachment) [28] or with a solution of $2 \mathrm{ml} \mathrm{HCl}, 98 \mathrm{ml}$ ethanol (95\%) (etching 2), suitable for microscopic examination of grain-boundary etch of tin-rich alloys (solder) [29].

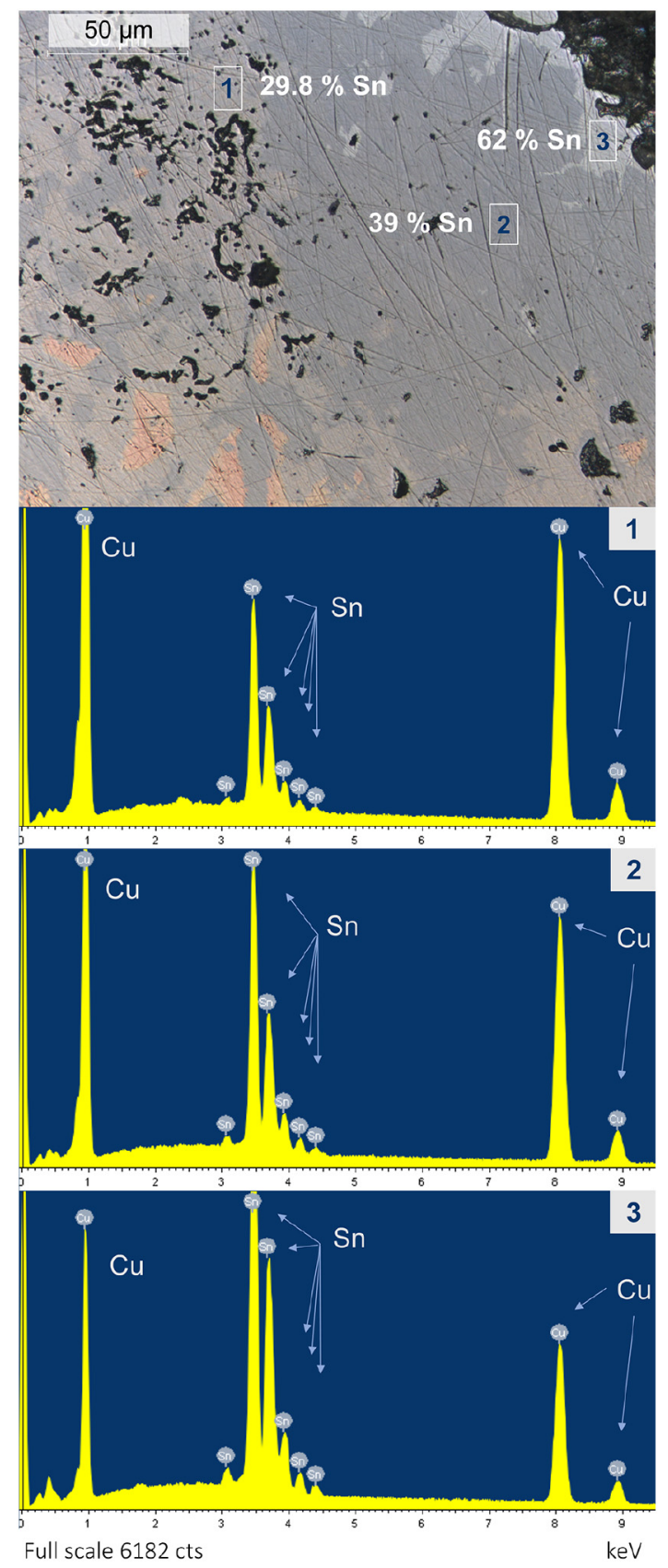

Fig. 5. OM image showing the sequence of the three different layers found in the solder of the attachment MA130 (the reddish zone at the bottom of the image is the bulk metal) with the corresponding SEM-EDS spectra.

\subsection{SEM-EDS}

SEM-EDS analyses were performed in a Zeiss DSM 962 scanning electron microscope coupled with an energy dispersive spectrometer from Oxford Instruments INCAx-sight equipped with a $\mathrm{Si}(\mathrm{Li})$ detector (133 eV at $5.9 \mathrm{keV}$ ) with an ultra-thin window for the detection of low atomic number elements. Semi-quantifications were made using ZAF correction method that calculates the compositionally dependent inter-element effects of electron scattering and energy loss according to the atomic number $(\mathrm{Z}), \mathrm{X}$-ray absorption within the specimen $(\mathrm{A})$, and secondary X-ray fluorescence characteristic emissions due to the self-absorption effect (F) [30].

Some SEM-EDS analyses were conducted in a variable pressure scanning electron microscope HITACHI S-3700N, with a secondary electrons detector (SE), backscattered electrons detector (BSE), and an energy dispersive spectrometer (EDS) XFlash 5010 Silicon Drift Detector (SDD) with a resolution of $129 \mathrm{eV}$ at $\mathrm{Mn} \mathrm{K} \alpha$, from Bruker. Standardless semi-quantifications were made using ZAF correction procedure in the Esprit1.9 $\mu$-analysis software from Bruker.

\section{Results and discussion}

The typology and elemental composition of the 10 anthropomorphic attachments and the situla (SIT153) analysed by micro-EDXRF is shown in Table 1 . The majority of the artefacts are leaded bronzes with highly variable $\mathrm{Pb}$ contents $(1.8<\mathrm{wt} \% \mathrm{~Pb}<25.0)$. Sn is present in lower amounts $(2.88<\mathrm{Sn} w \mathrm{t} \%<6.02)$. In some of the artefacts, $\mathrm{Zn}, \mathrm{Fe}, \mathrm{Ni}$ and As are also detected, although presenting low contents ( $<1 \mathrm{wt} \%)$. The wide range of $\mathrm{Pb}$ contents and the variability of the minor elements found in these artefacts suggest a poor formulation control during their production.

Observations of the attachments microstructure by OM and SEM reveal a typical as-cast structure with cored $\alpha$-Cu dendrites. Besides some $\alpha+\delta$ eutectoid in the Sn-richer artefacts, the interdendritic regions were found to be almost filled by Pb-rich phases, few CuS inclusions and microporosities (Fig. 2).

Preliminary visual inspection of the solder surface showed a generally darken (tarnished) layer. These observations also revealed that the solder was applied over a rough surface, exhibiting mechanical marks, such as grooves and parallel scratches (Fig. 3). The scratching of the attachment surface seems to be intentional. This mechanical operation should serve to the cleaning of the metallic surfaces prior to the application of a flux $[1,5,8]$. Fell [9] states that scratch lines observed might also be related to removal of old solder prior to repair.

Due to usual Sn stratified morphologies in solders [31], micro-EDXRF analyses were performed on uncleaned surfaces. The micro-EDXRF results show high variable $\mathrm{Cu}(\sim 77-21 \mathrm{wt} \%)$, Sn ( 61-18 wt\%) and $\mathrm{Pb}$ ( 2-17 wt\%) contents. However, analytical results by micro-EDXRF performed over these corroded and heterogeneous surfaces are highly influenced by several factors: compositional modifications including corrosion, in the burial context, which could involve important Sn and $\mathrm{Pb}$ enrichments [32]; a significant "substrate effect" (influence of the attachment composition) in the analysis; or even by high chemical segregations developed during the solidification of the solder.

Results obtained for the elemental composition of the solders after superficial cleaning are shown in Table 2. The main difference is the lower $\mathrm{Pb}$ contents in the cleaned areas, with one exception, in the MA035 solder analysis. However, it must be taken into account that the solder usually consisted of a very thin layer as it could be observed during the polishing procedure, which in some cases exposed some areas of the substrate. Besides to reinforce the idea of a possible significant influence of the substrate composition on the contents obtained, these results point to a higher $\mathrm{Pb}$ segregation to the outer layers of the solder.

Some authors [1,5] already warned to the fact that due to the very low thickness of the solder, the EDXRF results might be influenced by 
the composition of the substrate underneath. In this particular case, the effective penetration depth or the thickness from which $95 \%$ of the detected X-rays were produced was calculated (Table 3) using published values [33]. The values obtained for theoretical alloys with comparable composition estimate that the low energy Sn-L $\alpha$ comes from at least 5 $\mu \mathrm{m}$ depth.

In order to overcome the 'substrate effect', it was chosen to perform SEM analyses, since the penetration depth of the electrons is much lower than the X-rays of the micro-EDXRF (depth of emitted X-rays in SEM in metallic materials is $<2 \mu \mathrm{m}$ [30]). The solder remnants of the set of the attachments analysed by SEM-EDS in the cleaned areas showed a Sn-rich (approx. 30 to $60 \mathrm{wt} \% \mathrm{Sn}$ ) solder, with $\mathrm{Cu}$ and very low contents of $\mathrm{Pb}$, whenever detected. A deeper polishing in the previously cleaned areas, exposing part of the substrate, revealed a Sn increase in the interdendritic regions of the attachment close to the solder that was accompanied by a decrease of the $\mathrm{Pb}$ content. This compositional modification should be explained by local melting of $\mathrm{Pb}$-rich phase(s) in the substrate during the joining process, allowing a longrange diffusion of the Sn-rich solder into those interdendritic regions (Fig. 4) and a high contamination of the solder with the Pb released.

Another important feature in the substrate/filler interface is the existence of intermetallic compound layers. As an example, Fig. 5 illustrates the SEM-EDS results for the three intermetallic layers found in attachment MA130. It is worth to note that all layers present a binary $\mathrm{Cu}-\mathrm{Sn}$ composition. These layers could be described by an interdiffusion process between the Cu-rich substrate and the Sn-rich filler. Microanalysis of these layers showed that they are all $\mathrm{Cu}-\mathrm{Sn}$ rich, with the exception of the outer layer where $\mathrm{Pb}$ and other elements from soil contamination and corrosion processes ( $\mathrm{Fe}, \mathrm{Ni}, \mathrm{Al}, \mathrm{Si}, \mathrm{O})$ were also identified.
According to the binary equilibrium phase diagram for Cu-Sn system (Fig. 6) these intermetallic compounds layers should be the $\delta$ phase (chemical formula close to $\mathrm{Cu}_{41} \mathrm{Sn}_{11}$, with $\sim 32.6 \mathrm{wt} \% \mathrm{Sn}$ ), the $\varepsilon$ phase $\left(\mathrm{Cu}_{3} \mathrm{Sn}\right.$, with $\left.\sim 38.2 \mathrm{wt} \% \mathrm{Sn}\right)$ and/or the $\eta$ phase $\left(\mathrm{Cu}_{6} \mathrm{Sn}_{5}, \sim 61 \mathrm{wt} \% \mathrm{Sn}\right)$. The sequence of these intermetallic layers in the interface depends on the maximum temperature attained during the joining process. By atomic interdiffusion of $\mathrm{Sn}$ and $\mathrm{Cu}$, a $\delta$-layer is formed at temperatures between 350 and $580{ }^{\circ} \mathrm{C}$, a $\varepsilon$-layer is formed at temperatures under $660{ }^{\circ} \mathrm{C}$, while the $\eta$-layer is only formed under $415^{\circ} \mathrm{C}$. Taking into account the presence of $\mathrm{Pb}$ during the joining process, isothermal plots of the $\mathrm{Cu}-\mathrm{Pb}-\mathrm{Sn}$ ternary phase diagram were consulted [35]. These isothermal plots confirm that all those intermetallic compounds consist of binary Cu-Sn phases (Fig. 7) and, during the cooling, Pb is highly segregated to the remaining liquid. In this process, the last liquid, very poor in $\mathrm{Cu}$, should solidify in a $(\mathrm{Pb})+(\mathrm{Sn})$ eutectic. These last portions of solidification will help to explain the composition of the outer $\mathrm{Sn}-\mathrm{Pb}$ rich layer observed. The high contents of $\mathrm{Cu}$ in the outer layer (corroded) should be due to preferential leaching of copper corrosion products and its reprecipitation on the surface [36-38].

Fig. 8 outlines the layers' sequence identified by OM and SEM. The $\delta$ layer, relatively thinner than the others, could be observed on etched OM microstructures (Fig. 8a and c). On the other hand, the $\varepsilon$ and $\eta$ intermetallic layers presenting a higher difference between Sn contents are also enhanced by BSE (image by SEM) due to its higher atomic number contrast comparing to $\delta$ and $\varepsilon$-layer (Fig. $8 \mathrm{~d}$ ). In the same attachment, the $\delta$-layer (thinner layer), in certain regions is easily observed, while in others regions it is not. So, the non-observation of the $\delta$-layer in the selected areas of analysis cannot be conclusive. The outer layer regions from MA035, preserved at the bottom of the grooves, stands out in BSE-SEM image (Fig. 8 f), where the bright spots match the Pb-rich

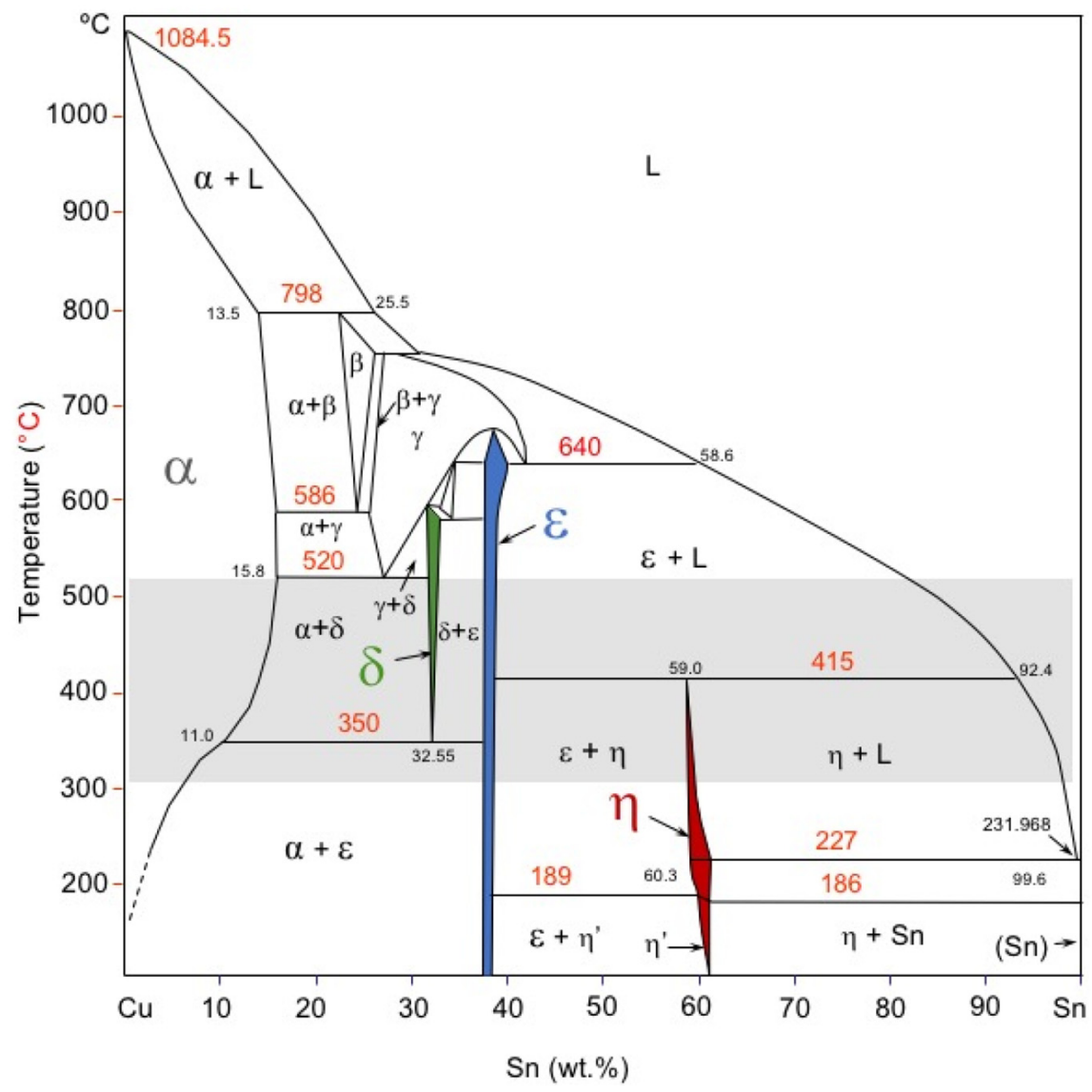

Fig. 6. Cu-Sn binary phase equilibrium diagram, adapted from [34]. The $\delta, \varepsilon$ and $\eta$ phases present different colours. 
phase. The Fig. 8eshows a schematic cross-section view exemplifying the complexity of intermetallic layers' morphology developed on a rough substrate, that helps to understand the range of compositions obtained and the corresponding phases.

The corresponding phase layers identified for each artefact are summarised in Table 4.

The $\delta, \varepsilon$ or $\eta$ intermetallic compounds could be formed by isothermal processes. According to the Cu-Sn binary phase equilibrium diagram (Fig. 6), the $\delta$ phase decomposes by an eutectoid reaction at $350{ }^{\circ} \mathrm{C}$. Although for common cooling rates the $\delta$ phase remains metastable at low temperatures [39]. The $\eta$ intermetallic phase (not in a uniform layer) could also be formed during cooling after the peritectic reaction at 415 ${ }^{\circ} \mathrm{C}$ by the subsequent solidification.

In all observations, the eutectoid structure layer resulting from the decomposition of higher temperature phases ( $\gamma$ and $\beta$ phases at 520 and $586^{\circ} \mathrm{C}$ ) was not found. So, the maximum temperature reached during the joining process should be inferior to $520^{\circ} \mathrm{C}$. The absence of these biphasic layers, comprising $\alpha+\delta$ phases at room temperature, points to Sn-rich solders.

This type of solder was commonly used for joining the stem and handles of bronze vessels in Greek and Roman times [3] and many components of these artefacts broke apart in the solder joint [40] just like the Conimbriga findings. In the studied artefacts, the soft solder applied provided a moderately stronger joint due to the deeper linkage of the filler through the melting of Pb-rich interdendritic channels and diffusion of the Sn-rich filler into the substrate (attachment). However, the presence of the segregated $\mathrm{Pb}$ on the opposite side (adjacent to the situla), previously diluted in the molten filler and coming from the diffusion process described earlier, would weak the joint.

The situla (SIT153) from Conimbriga presented a Cu-Sn alloy with $95 \mathrm{wt} \% \mathrm{Cu}, 4 \mathrm{wt} \% \mathrm{Sn}$ and $<1 \mathrm{wt} \% \mathrm{~Pb}$ (Table 1), the expected wrought alloy composition for this type of Roman artefacts produced by hammering a sheet of bronze [41]. The OM metallography of the situla revealed a homogeneous structure, composed by recrystallized Cu-rich grains, with the presence of a few and small size CuS inclusions and $\mathrm{Pb}$ globules. Comparing to Pompeii cauldrons and vessels analysed by Riederer [42] this situla presented lower Sn contents, although it is in agreement with the compositional range found in a large study of Roman thin bronze cauldrons from Holland by den Boesterd cited by Brown [43] and another study of similar artefacts from Scandinavia (Eastland bucket from [44]). With this composition, a hypothetical soldering between a situla and one of the studied attachments would certainly contribute to an enrichment of $\mathrm{Cu}$ and respectively reduction of the $\mathrm{Sn}$ ratios in the molten filler with the high Cu content of the situla - during interdiffusion processes in the interface filler/situla body. This hypothesis reinforces the $\mathrm{Sn}$ or Sn-rich solder stated to be used in the artefacts studied.

\section{Conclusions}

The investigation of solder remains in copper-based handle attachments of situlae from Conimbriga archaeological site has mostly identified a sequence of $\mathrm{Cu}-\mathrm{Sn}$ intermetallic phase layers by the interdiffusion between the filler and the substrate (handle attachment): $\eta$
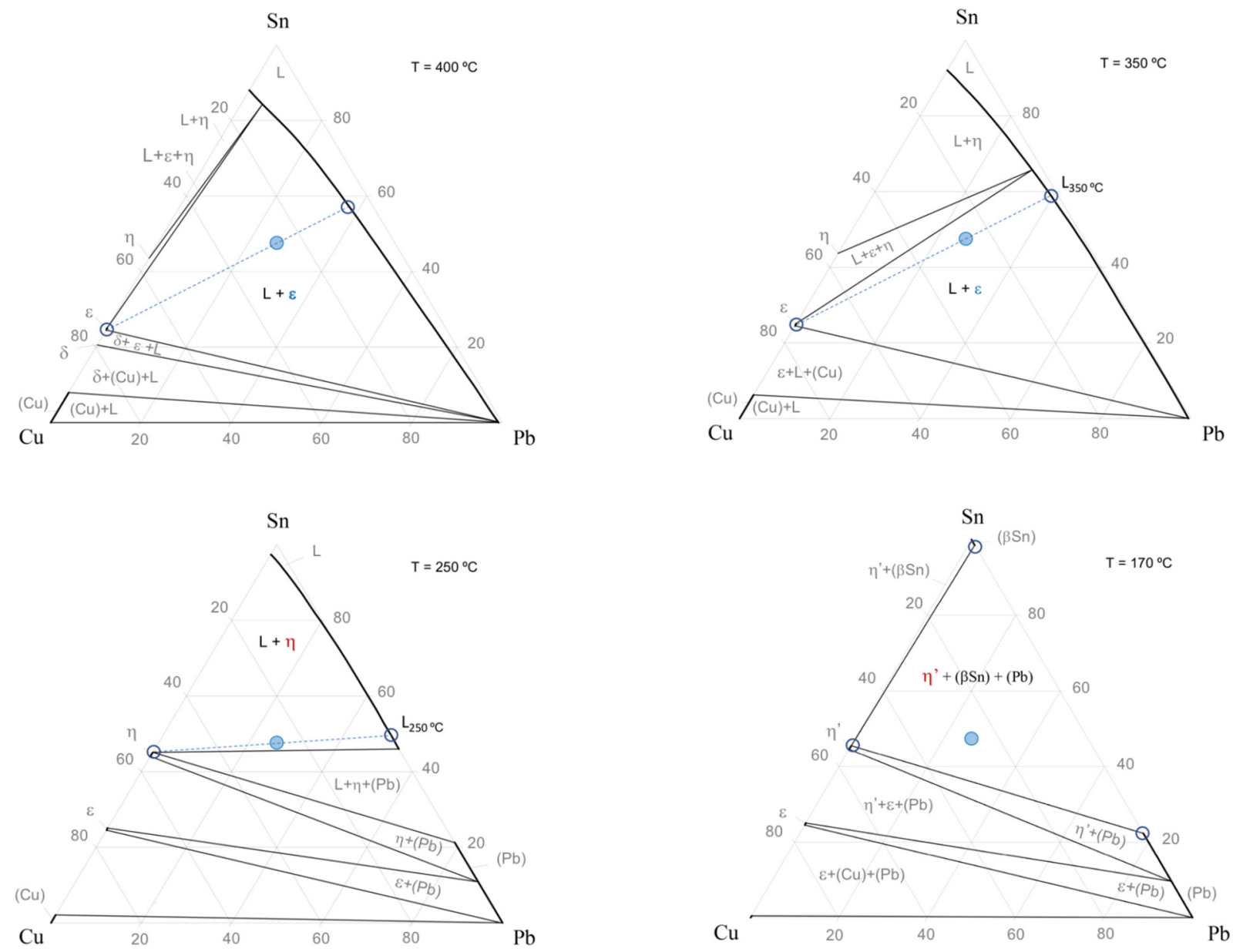

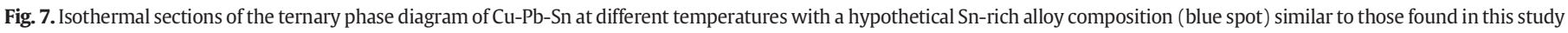

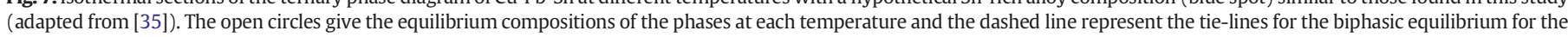
hypothetic alloy. 

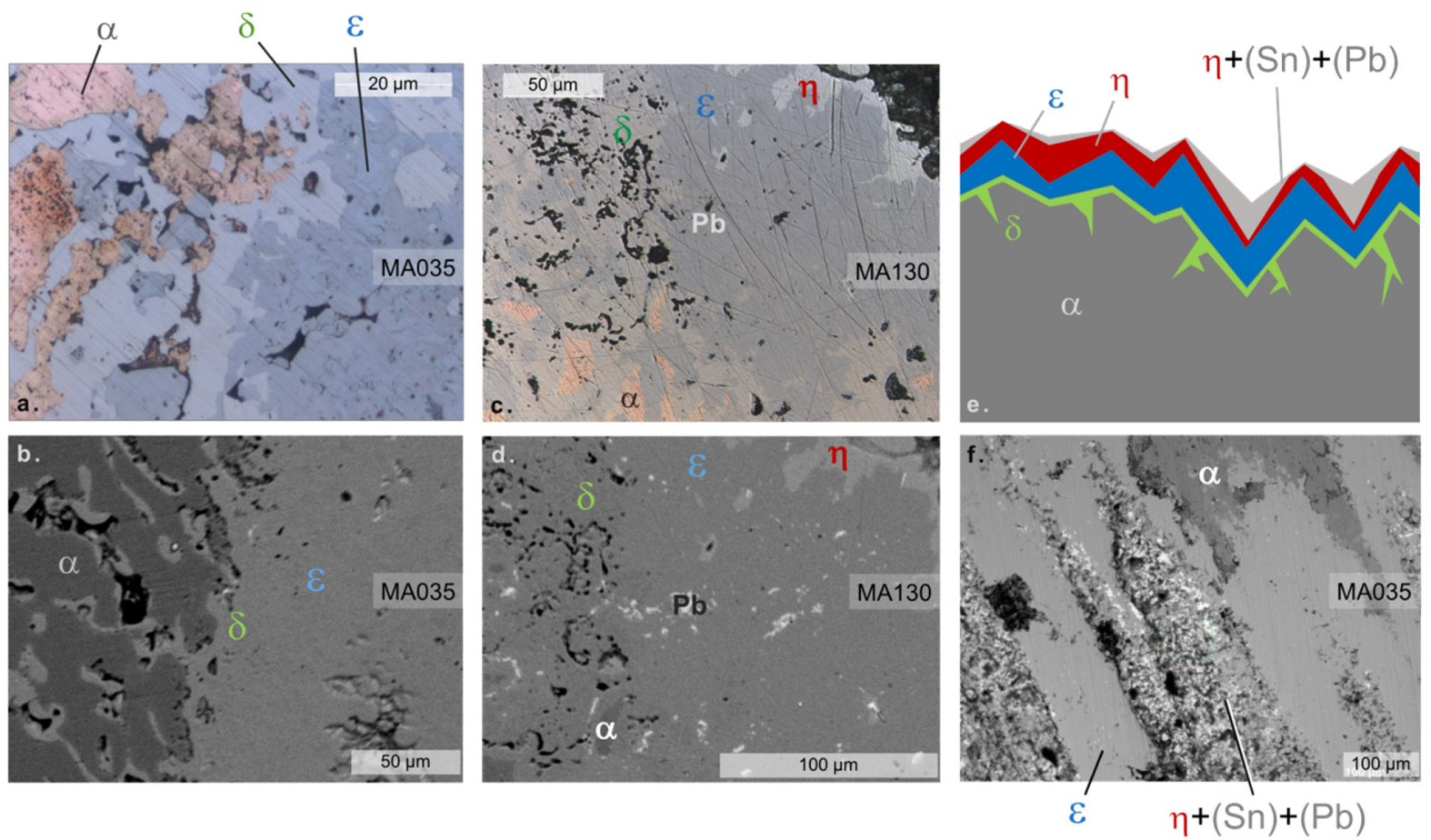

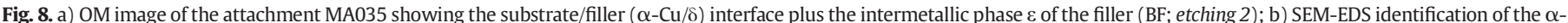

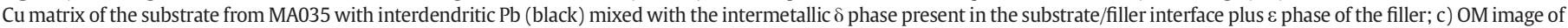

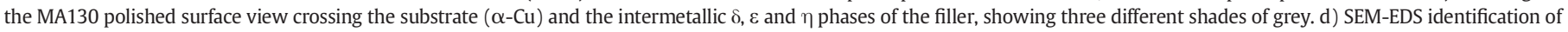

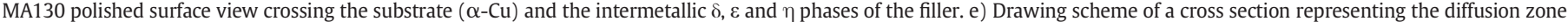

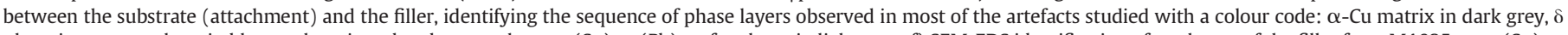

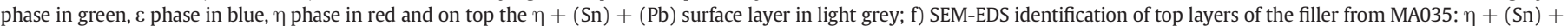
$(\mathrm{Pb})$. This image is representative of the roughness of some of the substrate/filler interfaces studied.

( $\sim 59 \mathrm{wt} \% \mathrm{Sn}), \varepsilon(\sim 38 \mathrm{wt} \% \mathrm{Sn})$ and $\delta(\sim 32.6 \mathrm{wt} \% \mathrm{Sn})$. The temperature reached during the joining process should be higher than $350{ }^{\circ} \mathrm{C}$ and lower than $520^{\circ} \mathrm{C}$. The fillers analysed point out to a $\mathrm{Sn}$ or $\mathrm{Sn}$-rich soft-solder.

Table 4

Intermetallic phase layers identified for each studied artefact; ( ): present; (?): inconclusive.

\begin{tabular}{|c|c|c|c|c|}
\hline & \multicolumn{3}{|c|}{ Intermetallic layer } & \multirow[b]{2}{*}{$\eta+(\mathrm{Sn})+(\mathrm{Pb})$} \\
\hline & $\delta$ & $\varepsilon$ & $\eta$ & \\
\hline MA017 & - & ○ & 0 & 0 \\
\hline MA021 & $?$ & - & 0 & - \\
\hline MA024 & $?$ & - & 0 & - \\
\hline MA028 & $?$ & ○ & 0 & 0 \\
\hline MA035 & - & - & 0 & - \\
\hline MA127 & $?$ & - & 0 & - \\
\hline MA129 & $?$ & - & 0 & - \\
\hline MA130 & - & - & $\bullet$ & - \\
\hline MA132 & - & $\bullet$ & 0 & ○ \\
\hline MA141 & $?$ & ○ & 0 & - \\
\hline
\end{tabular}

In some of the artefacts made by leaded coppers, it was observed an enrichment of the outer layers of the filler with lead from the substrate.

This study wishes to draw attention to the fact that a simple punctual analysis of a filler alloy may mislead the identification of the used joining technique, particularly a brazing which could most likely be a soldering. Due to the very low thickness of the filler, the EDXRF results might be influenced by the composition of the substrate underneath but also due to the interdiffusion of the chemical elements of the solder and the substrate that occurs when a certain temperature is reached and will gradually change the composition of the filler metal, preferably near the interface(s).

Considering the scenario of Conimbriga metallurgical production of handle attachments of situla, the low-temperature joining technique found within the studied artefacts, reveals an in-depth awareness of metallurgical techniques, in spite of the artefacts massive fabrication mainly based on issues of economic concerns and material availability.

\section{Acknowledgements}

Funding: This work was supported by FEDER funds through the COMPETE 2020 Programme and National Funds through FCT (Portuguese Foundation for Science and Technology), under project number POCI-01-0145-FEDER-007688, reference UID/CTM/50025/2013 to i3N/ CENIMAT and the project UID/Multi/04349/2013 to C2TN/IST. The PhD grant SFRH/BD/85329/2012 by FCT to FL is also acknowledged.

\section{References}

[1] E. Asderaki-Tzoumerkioti, Ancient and modern joining techniques on a bronze hellenistic urn, in: J. Ambers, C. Higgitt, L. Harrison, D. Saunders (Eds.), Proc. Conf. Hold. It All Together Anc. Mod. Approaches to Joining, Repair Consol, Archetype Publications. The Bristish Museum, London 2009, pp. 173-176. 
[2] H. Lechtman, A. Steinberg, Bronze Joining: a study in ancient technology, Art Technol. A Symp. Class. Bronzes, Massachusetts, MIT Press, Cambridge 1970, pp. 5-35.

[3] H. Maryon, Metal working in the ancient world, Am. J. Archaeol. 53 (1949) 93-125.

[4] Pliny the Elder, in: John Bostock, H.T. Riley (Eds.), The Natural History, Taylor and Francis, London, 1985 Book 34, Chapter 48 (17). Retrieved May 31, 2017, from http://www.perseus.tufts.edu/hopper/text?doc=Perseus\%3Atext\%3A1999.02. 0137\%3Abook\%3D34\%3Achapter\%3D48.

[5] M.J. Lang, J. Hughes, Joining techniques, Br. Museum Occas. Pap. 17 1991, pp. 169-177.

[6] J. Lang, M.J. Hughes, Soldering Roman silver plate, Oxf. J. Archaeol. 3 (1984) 77-107, https://doi.org/10.1111/j.1468-0092.1984.tb00124.x.

[7] R.W. Messler, Brazing: a subclassification of welding, Joining of Materials and Structures. From Pragmatic Process to Enabling Technology, Elsevier 2004, pp. 349-366.

[8] H. Maryon, Archaeology and metallurgy. I welding and soldering, Man 41 (1941) 118-124.

[9] V. Fell, Ancient fluxes for soldering and brazing, MASCA J. 2 (1982) 82-85.

[10] C.P. Swann, P.P. Betancourt, S. Fleming, C.R. Floyd, PIXE analysis of Trojan gold jewelry, Nucl. Instrum. Methods Phys. Res., Sect. B 130 (1997) 320-323, https://doi.org 10.1016/S0168-583X(97)00280-2.

[11] M.A. Ontalba Salamanca, G. Demortier, F.F. Gomez, P. Coquay, J.-L. Ruvalcaba-Sil, M. A. Respaldiza, PIXE and SEM studies of Tartesic gold artefacts, Nucl. Instrum. Methods Phys. Res., Sect. B 136-138 (1998) 851-857, https://doi.org/10.1016/ S0168-583X(97)00772-6.

[12] A. Wyttenbach, P.A. Schubiger, Trace element content of Roman lead by neutron activation analysis, Archaeometry 15 (1973) 199-207, https://doi.org/10.1111/j.14754754.1973.tb00090.x.

[13] E. Paparazzo, Surface and interface analysis of a Roman lead pipe "fistula": microchemistry of the soldering at the join, as seen by scanning Auger microscopy and X-ray photoelectron spectroscopy, Appl. Surf. Sci. 74 (1994) 61-72, https://doi. org/10.1016/0169-4332(94)90100-7.

[14] S.S. Gomes, P. Valério, L.C. Alves, M.F. Araújo, A.M. Monge Soares, V.H. Correia, Tin determination in fistula seals from Conimbriga and Augusta Emerita, Microchem. J. 124 (2016) 540-546, https://doi.org/10.1016/j.microc.2015.09.029.

[15] E. Anastasiades, Bronze welding, riveting and wiremaking by the ancient Greeks, Met. Prog. 58 (1950) 322-324.

[16] A. Azéma, B. Mille, P. Echegut, D.D.S. Meneses, An experimental study of the welding techniques used on large Greek and Roman bronze statues, Hist. Metall. 45 (2011) 71-80.

[17] M. Marabelli, The monument of Marcus Aurelius: research and conservation, in: D.A. Scott, J. Pod, B.B. Considine, Marina del Rey (Eds.),Anc. Hist. Met. Conserv. Sci. Res. Proc. a Symp. Organ. by J. Paul Getty Museum Getty Conserv. Institute, Novemb. 1991 1995, pp. 1-19.

[18] M.J. Hughes, Solders from classical to medieval times, in: J. Ellis-Jones (Ed.), Asp. Anc. Min. Metall. Acta of a Br. Sch. Athens Centen. Conf, Univ. Bangor, Bangor 1988, pp. 80-87.

[19] P.T. Craddock, Tin and tin solder in Sumer: preliminary comments, MASCA J. 3 (1984) 7-9.

[20] R. Dooijes, Ancient Repairs on Bronze Objects, EXARC, 2012.

[21] P. Craddock, Copper Alloys of the Hellenistic and Roman World: New Analyses and Old Authors, in: J.E. Jones (Ed.), Asp. Anc. Min. Metall. Acta a Br. Sch. Athens Centen. Conf. 1986, University College of Wales, Bangor 1988, pp. 55-65.

[22] F. Lopes, R.J.C. Silva, M.F. Araújo, V.H. Correia, Roman situlae from Conimbriga (Portugal): compositional and microstructural characterization of anthropomorphic handle attachments, Mater. Manuf. Process. 32 (2017) 827-835, https://doi.org/ 10.1080/10426914.2016.1221102.

[23] A. Pinto, Bronzes figurativos romanos de Portugal, Fundação Calouste Gulbenkian, Lisboa, 2002.
[24] J. Alarcão, R. Etienne, A.M. Alarcão, S. Ponte, Fouilles de Conimbriga VII, Trouvailles diverses, conclusions générales, De Boccard, Paris, 1979.

[25] H. Bronk, S. Röhrs, A. Bjeoumikhov, ArtTAX - a new mobile spectrometer for EnergyDispersive Micro X-Ray Fluorescence spectrometry on art and archaeological objects, Fresenius J. Anal. Chem. 371 (2001) 307-316, https://doi.org/10.1007/ s002160100989.

[26] P. Valério, M.F. Araújo, A. Canha, EDXRF and micro-EDXRF studies of Late Bronze Age metallurgical productions from Canedotes (Portugal), Nucl. Inst. Methods Phys. Res. B 263 (2007) 477-482.

[27] E. Figueiredo, R.J.C. Silva, M.F. Araújo, F.M.B. Fernandes, Multifocus optical microscopy applied to the study of archaeological metals, Microsc. Microanal. 19 (2013) 1248-1254, https://doi.org/10.1017/S1431927613001608.

[28] D.A. Scott, Metallography and Microstructure in Ancient and Historic Metals, The Getty Conservation Institute \& Archetype Books, Los Angeles, 1991.

[29] M.L. Bauccio, in: M.L. Bauccio (Ed.), ASM Metals Reference Book, 3rd editionASM International, Ohio, 1993.

[30] D.E. Newbury, N.W.M. Ritchie, Performing elemental microanalysis with high accuracy and high precision by scanning electron microscopy/silicon drift detector energy-dispersive X-ray spectrometry (SEM/SDD-EDS), J. Mater. Sci. 50 (2014) 493-518, https://doi.org/10.1007/s10853-014-8685-2.

[31] M. Schwartz (Ed.), Soldering: Understanding the Basics, ASM International, Ohio, 2014.

[32] E. Figueiredo, P. Valério, M.F. Araújo, J.C. Senna-Martinez, Micro-EDXRF surface analyses of a bronze spear head: lead content in metal and corrosion layers, Nucl. Instrum. Methods Phys. Res., Sect. A 580 (2007) 725-727, https://doi.org/10.1016/ j.nima.2007.05.135.

[33] R. Tertian, F. Claisse, Principles of Quantitative X-Ray Fluorescence Analysis, Heyden \& Son, London, 1982.

[34] ASM International, Metals Handbook, Volume 8: Metallography, Structures and Phase Diagrams, 8th edition American Society for Metals, Ohio, 1970.

[35] K. Korniyenko, Cu-Pb-Sn (Copper-Lead-Tin), in: G. Effenberg, S. Ilyenko (Eds.), NonFerrous Met. Syst. Part 3 Sel. Solder. Brazing Syst, Springer Berlin Heidelberg, Berlin, Heidelberg 2007, pp. 368-373, https://doi.org/10.1007/978-3-540-47004-5_32.

[36] L. Robbiola, J.-M. Blengino, C. Fiaud, Morphology and mechanisms of formation of natural patinas on archaeological Cu-Sn alloys, Corros. Sci. 40 (1998) 2083-2111, https://doi.org/10.1016/S0010-938X(98)00096-1.

[37] L. Robbiola, R. Portier, A global approach to the authentication of ancient bronzes based on the characterization of the alloy-patina-environment system, J. Cult. Herit. 7 (2006) 1-12, https://doi.org/10.1016/j.culher.2005.11.001.

[38] R. Walker, Corrosion and preservation of bronze artifacts, J. Chem. Educ. 4 (1980) 277-280.

[39] Centre Technique des Industries de la Fonderie, Atlas Métallographique des Alliages Cuivreux, Éditions des Industries de la Fonderie, Paris, 1967.

[40] G. Richter, Greek, Etruscan and Roman Bronzes, Metropolitan Museum of Art, New York, 1915

[41] J. Riederer, The use of standardised copper alloys in Roman metal technology, in: A Giumlia-Mair (Ed.), I Bronzi Antichi Prod. E Tecnol. Atti Del XV Congr. Internazionale Sui Bronzi Antichi, Grado-Aquileia, 22-26 Maggio 2001, Mergoil, Monique, Montagnac 2002, pp. 284-291.

[42] J. Riederer, Die Berliner Datenbank von Metallobjekten kulturgeschichtlicher Objekte, III. Römische Objekte, Berliner Beiträge Zur Archäometrie, 18, 2001, pp. 139-259.

[43] D. Brown, Bronze and Pewter, in: D. Strong, D. Brown (Eds.), Rom. Crafts, New York University Press, New York 1976, pp. 25-41.

[44] H. Bollingberg, U. Hansen, Roman cauldrons in Scandinavia: major and minor element analyses, in: S. Mols, et al., (Eds.), Acta 12th Int. Congr. Anc. Bronzes, NAR18, ROB, Amersfoort 1995, pp. 131-136. 